\title{
Landscape Subsection
}


Jesse Toufexis

Introduction: Carved into Rock and Labelled with Hebrew Script: Thinking about the Canadian Jewish Landscape 
The relationship between Jews and the Canadian landscape opens an avenue of inquiry in Canadian Jewish Studies that has not yet been explored to its fullest potential. Though this avenue of inquiry is hard to pin down, I offer a short introduction here to beg expansion in the future. The field of Landscape Studies, a "classic transdisciplinary concept" which I describe in the following pages, is emerging elsewhere in academic communities, and it is my sense that many of our scholars in this field have in fact been engaging with it to varying degrees for a number of years already, though perhaps unbeknownst to us.

Jewish voices across centuries speak of new homes in specifically Jewish terms, as if they are carrying their mythic geography with them-the holy mountains, rivers, caves, and towns of legend-and projecting it onto the landscape of whichever place they sojourn. Indeed, the Jewish people carry cultural memories of a Home that might not have been home for generations and generations of their forebears. A large number of Canadian Jews today are not themselves immigrants, and a smaller but sizeable number are even two and three generations removed from their family's first steps on Canadian soil. For many Jews, Canada is home, the home of parents, and was even home to parents' parents. In many ways, these generations steeped in Canada's views have removed Jews from the fundamental alterity their forebears experienced when they first arrived at a Canadian harbour, many times on the beautiful maritime coast. From Nova Scotia inwards to New Brunswick, further to Montreal, and to Toronto, Winnipeg, and into the depths of the Prairies until the Rocky Mountains and the Pacific Coast (and, of course, the other way around), the Canadian landscape had to have been strange in the strictest sense; alien; otherworldly.

The trek across the ocean landed these individuals in unfamiliar surroundings that promised opportunity, safety, and occasion for commercial enterprise. That being said, that unfamiliarity had to have been trying; for many, this opportunity meant separation from parents, grandparents, cousins, aunts and uncles, friends, and even spouses and children. It also meant an unending encounter with languages to which they were unaccustomed, and cultures that looked upon them with varying degrees of suspicion. In essence, there was great potential for unbearable loneliness, both as individuals and as a community. Canadian landscapes-rural and urban; physical and sensorial-would be a constant reminder of this enormous distance.

Jewish immigration to Canada was, of course, not the first time in history that Jews found themselves leaving their home for ostensibly better opportunities. The experience of uprootedness, of movement and transit, of temporary settlement, is not new, and in fact has been discussed in myriad times and places by scholars of the Jewish experience. As David S. Koffman points out in his introduction to the recent volume No Better Home? Jews, Canada, and the Sense of Belonging, "In Jewish history, the experiences of leaving homes, of remembering left homes, of pining for a home 
away from home, or finding otherworldly homes or homes in text, have been woven deep into the fabric of Jewish culture."

In the following pages, I will flesh out the idea of Landscape Studies with a special focus on the opportunities available to Canadian Jewish studies. First, though, we might illustrate one approach to the theme with a few brief examples of our scholars already making contact with it. Vardit Lightstone, writing about the memoirs of Yiddish-speaking immigrants to Canada in vol. 29 of Canadian Jewish Studies in 2020, offers one such example. Lightstone discusses Jewish immigrant Falek Zolf's thoughts on his arrival to Canada, recorded in his journal. On taking the train from Halifax to Montreal, she writes, Zolf conjures the "Po-lin" legend, popular among contemporary Polish Jews. Lightstone explains, "As he passed forests and mountains, he thought about how far he was from where his ancestors lived." 3 Reflecting on the alterity of the landscape, he thinks back to that legend:

That's how it was once, a thousand years ago, the "exiles of Ashkenaz" went looking for a new land. And when they arrived at a forested steppe, as the legend says, they found a paper on the ground with the words "Po-lin," rest here, make this your harbour. The exiles immediately settled on the new, raw land and with their blood and sweat built up the Jewish settlements of Poland. ${ }^{4}$

Lightstone continues, "The first Jewish residents of Poland, like the early Eastern European Jewish residents of Canada, went through a process of culture shock and creative adaptation, one expression of which was this legend."' By superimposing the Polish landscape-and Polish Jewish mythic view of it-onto the Canadian landscape, Zolf was able "to incorporate this new place into a Jewish worldview, to creatively possess it."

While Lightstone's analysis is of a primary source, we also find scholars projecting a Jewish landscape onto the Canadian in their own analyses of primary sources. Michael Greenstein's acclaimed study of Canadian Jewish writing, Third Solitudes, for example, utilizes the image of the legendary Sabbath river, Sambation, to discuss the boundary-challenging power of Canadian Jewish writing. First, Greenstein explains the river itself, writing, "According to legend, some of the ten 'lost tribes' of Israel were exiled beyond Sambation, the raging river which is calm only on the Sabbath when crossing would be possible but prohibited by law-a Kafkaesque or catch-22 dilemma." Greenstein explains that Sambation's impossible crossing symbolizes "a dividing line between centre and circumference, Zion and Diaspora, origin and margin, presence and absence, sacred and profane, accomplishment and deferment, tradition and adventure, promised land and desert." ${ }^{8} \mathrm{He}$ also makes the superimposition of Jewish mythic geography onto the Canadian landscape explicit, writing, "Sambation flows endlessly with hidden undercurrents; its Canadian tributaries are the St. Lawrence, and further west, Ludwig's, Waddington's, and Wiseman's Assini- 
boine, Mandel's Souris, and Kreisel's Saskatchewan."9 In a similar vein, consider Allan Levine's choice of the title Seeking the Fabled City for his expansive account of the Canadian Jewish experience, or Gerald Tulchinsky's assertion in Canada's Jews: A People's Journey that the Jewish quarter in Winnipeg's "vibrancy made the district a unique and culturally rich place, a veritable Vilna - the lively Lithuanian city of unparalleled Jewish intellectual life-a landscape of restaurants, delicatessens, bakeries, barbershops, bookstores, photo studios, markets, synagogues, schools, and other centres set in this Prairie metropolis of frigid winters and scorching summers." ${ }^{\text {"Ir }}$ As we can see here, it is not only the objects of our study, but we ourselves as scholars, who take part in the enterprise of landscape projection, as we might call it.

\section{Landscape Studies is a Broad Area of Scholarship}

Now, my area of interest is literature, so the most prominent examples that jumped out at me in such a lively manner had to do with writing and studies of writing. But Landscape Studies as a discipline goes far beyond my narrow purview, and I believe a brief explanation would be useful here. Howard et al. explain that Landscape Studies is "an extraordinarily vibrant field of research, fuelled by nuanced and complex approaches that draw from a wide array of disciplines-history, geography, archaeology, tourism, art history, heritage, anthropology, architecture, planning, philosophy, law, ecology, psychology and education, to name but a few."12 They explain that there is no single perspective, approach, or framework that is most appropriate to understand landscapes, and write, as I mentioned earlier, that Landscape is "a classic transdisciplinary concept."'13

Not only is there no singular perspective that should be utilized in this field, but there is hardly agreement on how exactly to define the term Landscape itself, leaving it open-ended and up to the scholars who wish to partake in its study. The editors offer a few ideas that are by no means final. Quoting contributors from within their Rutledge Companion to Landscape Studies (2020), they give us four possibilities: ${ }^{14}$

I) [Landscape] is at once the relationship between humans and their surroundings, and the confluence of physical subsistence and psychological necessities.5

2) [Landscape] is a reflection of human interaction with natural forces. ${ }^{16}$

3) Landscape is evidence of cosmological processes that define kinship, group alignments and cultural practices. ${ }^{17}$

4) Landscape is a vague concept and in reality has fuzzy edges. And yet we know what we mean and can spot when the term is being stretched, used metaphorically or misapplied..$^{18}$ 
Perhaps these definitions muddy the waters more than clarify them, but there is a strong sense here that Landscape as a scholarly concept is not made up only of natural forces, but the interaction between those forces and humans in some sort of symbiotic relationship. Howard et al. continue this line of thinking, writing that "human beings need to be able to relate to their surroundings and [. . . landscapes provide psychological sustenance as much as they support physical subsistence." ${ }^{\prime \prime 9}$ Discussing an experimental psychology approach to Landscape Studies, they write about a hypothesis that indicates "humans are hard-wired to prefer landscapes similar to those in which we had successfully survived and evolved."2o Though they are discussing something on the level of eons here, it is not hard to see how Jewish superimposition of biblical and post-biblical geography onto the landscapes of their adoptive homes might fit into this analysis. Through years of hardship and movement, the impulse to return mentally to that moment-a standing Temple, or a land their own, or a time of great spiritual activity and study-can offer a sense of comfort in an alien world. We have already seen this in a Canadian context in Lightstone's article, but the possible avenues for Canadian Jewish Studies are many.

As a glimpse of the various topics related to Landscape Studies, we might look at some of the approaches in that Routledge publication, including those of environmental psychology, postenvironmental landscapes, semiotics, pedagogy, phenomenology, archaeology, history, art, film, photography, sonic environments, tourism, economics, social justice, memory, architecture and urban planning, and many others. As I will point out in the following pages, many works of Canadian Jewish scholarship could easily be reframed and understood in these contexts.

Thinking more about how the Jewish experience might fit into this scholarly landscape, and given the unique ethno-religious status of the group, we might shift to a study of Religion and Landscape. Scholars in both Canada and the United States have taken up this focus, with Frances Swyripa's monograph Storied Landscapes: Ethno-Religious Identity and the Canadian Prairies bringing Canada into focus. ${ }^{21}$ Advocating for further studies into the effect of the landscape on religious practice in the United States, Michael Pasquier writes,

From theological formulations to ritual practices, the shape of religion often depends on its placement in specific landscapes and its responsiveness to environmental conditions that are often unique to different times and spaces. The religious contours of life along the Mississippi River, for example, are in many ways different from those of rural regions like Appalachia and urban regions like the San Francisco Bay precisely because of their relationship to the natural and built environment. ${ }^{22}$ 
Bringing Simon Schama's seminal book Landscape and Memory (1995) into the discussion, Pasquier notes that "there are features of the natural and built environment that are 'often hidden beneath the layers of commonplace' that require 'an excavation below our conventional sight-level to recover veins of myth and memory that lie beneath the surface."' ${ }^{23}$ Indeed, as we will see in some of the articles that follow in this section, "veins of myth and memory" do lie beneath the surface, awaiting excavation by scholars. The impulse to flood one's conceptualization of their surroundings with the vast Jewish imaginary is a strong one, and often manifests implicitly rather than explicitly. In a Religious Studies approach to this topic, scholars could look into the ways in which the Hasidic community conceptualizes the Canadian landscape in familiar terms in their writings, for example.

\section{Space, Place, and Landscape are Emerging in Broader Jewish Studies}

Jewish Studies outside of Canada has engaged with Landscape Studies, perhaps not always directly but adjacently, through studies of Jewish space and place. An essential read in this domain is a collection of essays entitled Jewish Topographies: Visions of Space, Traditions of Place (2008), edited by Julia Brauch and Anna Lipphardt. In it, the two editors note that "Jewish religion is seen as transcending or even substituting specific places or spaces, as the foundation uniting the Jewish people despite the differences that derive from the multitude of geographical localities in which Jewish communities and individual Jews have settled." ${ }^{24}$ They make an important differentiation between Jewish place and Jewish space, claiming that

Jewish places are, in our understanding, sites that are geographically located, bound to a specific location, such as the Jewish quarter in Fez, Morocco, or the gravesite of Baba Sali in Netivot, Israel. Jewish spaces are understood as spatial environments in which Jewish things happen, where Jewish activities are performed, and which in turn are shaped and defined by those Jewish activities, such as a sukkah or a Bundist summer camp for children. Therefore, in our understanding Jewish place is defined by location, Jewish space by performance..$^{25}$

While Jewish places have been studied since the inception of what we now call Jewish Studies, Brauch and Lipphardt argue that Jewish space remains under-researched. "It has neither been included," they say, "into general space studies, such as geography, architecture, urban and landscape planning, nor systematically integrated into Jewish studies, as a subdiscipline or research field, as a research object or perspective, or a key concept."26

While Landscape Studies is not the named area of inquiry in their introduction, the group of authors and essays in the book operate, in many ways, as if it was. Again, 
given the nebulous nature of Landscape Studies, it is no surprise that it fits in and out of a variety of fields and subfields, perspectives and methodologies. In the only chapter that has to do with Canada, for instance, Etan Diamond writes about a Jewish suburban development in Thornhill, Ontario. ${ }^{27}$ When we think about Jews and the Canadian landscape, what more explicit study could we find than a Jewish subdivision literally carved out of Canadian rock in the Toronto suburbs?

In 198I, Diamond explains, a real estate developer by the name of Joseph Tanenbaum planned to create a new subdivision in rural Thornhill, near Toronto. It had all the makings of a typical suburban development, Diamond explains, "but whereas other new suburban developments stopped there, Tanenbaum went one step further, and planned for a synagogue-community center that would act as the anchor for the entire new community"28 While Tanenbaum's contemporaries thought that his plan would fail, Diamond explains that a quarter-century had passed at the time of writing, and the results were truly astounding:

With more than 20,000 Jews living in well-kept middle-class and upper-middle class subdivisions-about one-third of the total population in the areaThornhill is home to a dynamic mix of Ashkenazic and Sephardic Jews, Russian, South African, and Israeli Jews, along with those families who have lived in Toronto for several decades. There are Orthodox, Conservative, Reform, and completely unaffiliated Jews. And there are the institutions: more than a dozen Orthodox synagogues, four Jewish day schools, numerous kosher restaurants and food stores, Judaica and Jewish bookstores, and two Jewish social service agencies. ${ }^{29}$

Carving Jewish space out of the Canadian landscape-in an extremely literal sense in this case-has not only manufactured a Jewish space, but altered the landscape into something we could call Canadian Jewish, rather than one separate from the other. There are two broader takeaways from Diamond's chapter: the first is that, despite the names given to the field of study in Brauch and Lipphardt's volume, the ideas therein help us reframe scholarship already published and draw a bigger circle around new questions still unstudied. And secondly, it is a prime example of another direction such a field of study could go, as it is a study in urban planning rather than the literary focus that I have thus far presented. Studies of Canadian-Jewish neighbourhoods, though not labelled as Landscape Studies, abound when we consider the physical placement of the so-called Third Solitude in Montreal-the Jewish quarter that was historically wedged between the French and English sides of the city along the border of Boulevard St. Laurent. ${ }^{30}$ But other such studies exist outside of the typical thoroughfares in Montreal and Toronto, like Henry Abramson's article from twenty years ago, "Just Different': The Last Jewish Family of Ansonville, Ontario."3r Abramson's article makes mention of his "regular pilgrimages" to the small Jewish 
cemetery in the area, and it is in these loci of remembrance that Norman Ravvin situates his article in this section, entitled "Placed Upon the Landscape, Casting Shadows: Jewish Canadian Monuments and Other Forms of Memory." Here, Ravvin looks at Canadian Jewish sites of remembrance and reflects on their ability to transform a Canadian landscape into a Jewish one through many means but especially language. He writes of gravestones that "throw shadows this way and that, as a statue does, and [...] offer a varying array of inscriptions. Most markings on Jewish gravestones are in Hebrew, a language that non-Jewish Canadians do not read, so these remain coded inscriptions. But one can begin to decipher something on most Jewish gravestones."

Elsewhere in Brauch and Lipphardt's volume, we find more chapters unwittingly dedicated to Landscape. One of them is Haya Bar-Itzhak's chapter, "Poland: A Materialized Settlement and a Metaphysical Landscape in Legends of Origin of Polish Jews." In this chapter, and in keeping with the Landscape discussion that began my introduction, Bar-Itzhak notes that "an analysis of the legends shows that Poland was viewed not just as a materialized settlement, but also as a metaphysical landscape. In other words, the geography of Poland became the geography of the Jewish imagination." ${ }^{32}$ Discussing specific legends in which geographical features like caves and forests are transformed into sacred places of Jewish worship, Bar-Itzhak writes,

The legends show how landscape and human beings create each other and influence each other. Human beings project their inner world on the topography and landscape of the place, giving them a new symbolic meaning for both the individual and the community. It was this endowment with meaning that gave the Jews a sense of deep-rooted connection to Poland. ${ }^{33}$

Again, though Brauch and Lipphardt's volume is officially a book about "place and space," it is evident from this quote that those terms are interchangeable with Landscape. Taken with the earlier assertion by Howard et al. that "[Landscape] is a reflection of human interaction with natural forces," the opening line of the previous Bar-Itzhak quote forms a natural connection between the two areas of study. The landscape - for our purposes Canadian - is not a monolithic ecosystem, static for every human and every culture. Rather, each individual and each group forms a unique landscape, just as much as the landscape influences the individual and the group. My own article in this subsection, on the mythic geography of Jewish authors in Montreal, ${ }^{34}$ explores this theme through an examination of their interaction with the city's "holy mountains," Mount Royal and its geological kin in the Laurentians. By making use of the vast Jewish dreamscape - that place where the Jewish cultural imaginary dwells, with its rivers, forests, paths, and in this case especially mountains - these authors make Montreal more familiar; more Jewish. 
There are plenty more instances in Brauch and Lipphardt's volume that fit in with our Landscape discussion. In the interest of brevity, I will only mention a couple of them here. In her chapter, "Desert and Settlement: Space Metaphors and Symbolic Landscapes in the Yishuv and Early Israeli Culture," Yael Zerubavel writes that Israel's desert locale was emphasized in early Zionist writings in order to give the sense that the "land of milk and honey" had fallen into disrepair and desolation while they were "away from home," as it were. By doing this, they "[represented] it as a moral imperative and a debt to the national past as well as a means to advance the cause of future national redemption."35 She also notes that, despite the fact Arab and Jewish settlements "existed next to each other in physical space," the landscape in between Jewish settlements was conceptualized as a total desert. ${ }^{6}$ Thinking of this theme of travel on a Jewish frontier, I am reminded of one of my personal favourite recent articles in the field, Richard Menkis's "Two Travellers and Two Canadian Jewish Wests," in which Menkis compares the travels of two prominent rabbis on the Canadian frontier to a phenomenon that took place in Israel, writing, "Hertz's pastoral tour and Horowitz's travels in Western Canada are variants of a better-known phenomenon: the wandering emissary for Jewish institutions in the Land of Israel." ${ }^{37}$

A landscape can be any number of things. In Eve Jochnowitz's chapter, "Foodscapes: The Culinary Landscapes of Russian-Jewish New York," the author notes four important landscapes for culinary-cultural study: the mouth, the table, the kitchen, and the street. "As a liminal zone, neither outside nor inside," she writes, "the mouth is a particularly contested cultural landscape. ${ }^{38}$ In fact, she writes, "all of culture passes through the mouth." ${ }^{39}$ Our Canadian scholars have taken up the question of foodways and foodscapes as well, one example being found in Roginsky and Cohen's article "Trading Jerusalem: Jewish-Arab Encounters in a Middle Eastern Restaurant in Toronto" in Canadian Jewish Studies.$^{40}$ In this article a single restaurant in Toronto becomes a locus for assessing intercultural dynamics, including the visual landscape of the restaurant itself, right down to its logo. Of course, the work of Norma Baumel Joseph on the foodscapes of Iraqi Jews in Canada comes to mind as well, as we consider her notion that "Foodways are cultural highways," and that culinary patterns "link individuals to communities, while nourishing connections to a past heritage or to a sacred concept of 'home."'4t

Finally, Miriam Lipis discusses the construction of sukkahs in urban spaces. Writing about the tension between diaspora and belonging that takes place in the building of a sukkah, Lipis notes that "a sukkah constructs and expresses a hybrid concept of places of belonging, which overcomes the dichotomy of having or not having a place of belonging, by superimposing several real and imagined places. Thus, constructing and expressing both: a sense of belonging and a longing for another place." ${ }^{42}$ In this way, Jewish inhabitants carve their own views into cityscapes. In our volume, Aubrey Glazer tackles an adjacent topic as he discusses Hasidic dress in Boisbriand, which 
alters the visual landscape of the neighbourhood in his article "Third Solitudes Without Separation, Oneness Torn from the Other: On Tearing Through the Shroud of the Solitude of Montreal Jewish Mystics. Glazer notes, "By dressing modestly in Hasidic garb, the adherent is able to maintain the necessary solitude that separates culture without separating from the shared landscape of Boisbriand." If we were to think of the other notable Hasidic neighbourhoods in Montreal, like Outremont and Mile End, we would see that the impact of Hasidic dress on the urban landscape is famed and undeniable. The landscape of Outremont and Mile End would simply not be the same without the visual cues of Hasidic dress, and are regularly noted in Jewish and non-Jewish writing and reporting alike.43

\section{In Canada, Landscape Studies Focuses on the Environment}

Catherine Caufield's article in this section, entitled "Landscapes of Poetic Transformation", explores the works of Canadian Jewish women poets Miriam Waddington, Karen Shenfeld, Anne Michaels, and Rhea Tregebov, reflecting on their usage of the "iconic Canadian landscape - the northern lakes, rocks, and forests" to mediate their work. "An enduring stereotype," write Can-Lit scholars and editors Ella Soper and Nicholas Bradley, "holds that Canadian literature revolves around descriptions of nature." 44 That same focus on nature holds true for Canadian discussions of the landscape. Less concerned with the various forms and definitions of landscape we might find in Howard et al's survey, scholarly discussions of landscape in Canadian studies have in recent years foregrounded the environment itself, manifest, for example, in the field of Ecocriticism, an approach to literary studies that focuses its investigation on "the many ways in which culture and the environment - the realm that both includes and exceeds the human-are interrelated and conceptualized."45 Ecocriticism forms the foundation of their edited volume, Greening the Maple: Canadian Ecocriticism in Context (2013). While that might sound quite broad, Soper and Bradley note that "it has tended, especially at its outset, to focus on literary representations of the natural world." ${ }^{46}$ The most prominent theme of ecocriticism since the early ig9os is that of environmental crises, and how Canadian authors approach and reflect upon them in their writing, owing to a shift in the humanistic disciplines "to make the environment the prime object of study."47

The subject of that volume is Canadian literature, but the editors do note that ecocriticism is increasingly "diverse in its concerns and techniques, and in intellectual traditions that it claims. ${ }^{38}$ Indeed, scholars in other fields have bought into discussions of the Canadian environment, with a prominent example to be found in Sean Kheraj's Inventing Stanley Park. In thinking about the creation of the acclaimed Stanley Park in Vancouver, Kheraj notes that, somewhat ironically, this attempt to create a space for nature required an exorbitant amount of human activity. He writes, "The creation of Stanley Park imposed a new set of ideas and values, but far from elim- 
inating the human presence in the peninsula, it required a massive human effort." Connecting the park to our previously discussed idea of a mythic past, Kheraj points out that "Stanley Park has become a symbol of an imagined past, a static portrait of a pre-colonial wilderness that never existed." ${ }^{49}$

Jennifer Bonnell also considers environmental impacts in her monograph Reclaiming the Don, in which she explores the ways in which the Don River Valley has impacted-and been impacted by-the establishment and growth of the city of Toronto. Over the years, she notes, the river has "claimed an important place in the history of ideas about the city and its future, its landscapes conceived by different groups in different periods as verdant wilderness, picturesque countryside, polluted periphery, predestined industrial district, restorative retreat, vital refuge, dangerous underworld." ${ }^{\circ 0}$ Considering the scope of Ella and Soper's book, and of Kheraj and Bonnell's monographs, we might say that, though the methodological approaches differ, the focus of Canadian Landscape Studies is on the environment in a way that is rather unique. Soper and Bradley note this, writing, "A preoccupation with nature is a widely acknowledged (and, yes, somewhat stereotypical) characteristic of Canadian literature."'s We can see that this preoccupation goes beyond the bounds of literary studies.

\section{The Canadian Jewish Landscape is Begging to be an Object of Study}

As we have seen, there is a rich, emerging field of study related to human interaction with landscapes. What the latter term even means is up for debate and interpretation, and leaves us with seemingly infinite avenues to pursue. We have also seen that the study of Jewish place and space is another emerging field, and that the field is closely related to that of landscape without labelling itself as such. Studies of Jewish urban planning, of literature, of early twentieth century Israeli discourse, all point to the varying methodologies one could take to approach such a broad topic. In Canada, though mostly informed by discussions of the environment, Landscape Studies has emerged significantly in the last ten years. And though all of these fields go by different names, we have seen that they are all in varying degrees of contact with each other, indicating that there is a desire to pursue studies related to humans, nature, and whatever it is that the collision of the two creates, whether that be cityscapes, superimposition of mystical narratives, or something of a totally different sort.

This subject is open to interpretation. Though three of the four articles in this section have mostly to do with literary concerns (and the last incorporates them as well), this is much more of a coincidence than a rule. Just as much as one could write about literary or mystical projection of Jewishness onto a perceived Canadian landscape, one could write about physical Jewish zones carved into rock, built upon, and labelled with Hebrew script, signalling to the world their fundamental Jewishness. 
In the future, my hope is that this section will pique the curiosity of our wonderful scholars in such a way that we could produce a volume with contributors from all corners of the scholarly landscape: history, geography, literature, urban planning, health sciences, linguistics, religion, sociology, anthropology, and every other path that leads to this space we call Canadian Jewish Studies. For now, though, I simply hope that you will enjoy the four articles that follow.

\section{1}

Peter Howard et al., eds., "Ways of Knowing and Being with Landscapes: A Beginning," in The Routledge Companion to Landscape Studies (London: Routledge, Taylor \& Francis Group, 2019), pp. xix-xxviii. Pg. xx.

\section{2}

David Koffman. "What Does It Mean to Ask the Question, 'Has There Ever Been a Better Home for the Jews than Canada?'" in No Better Home?: Jews, Canada, and the Sense of Belonging (Toronto: University of Toronto Press, 2021), pp. 3-15. Pg. 4.

\section{3}

Vardit Lightstone (2020). “Becoming Canadian: Folk Literary Innovation in the Memoirs of Yiddish-Speaking Immigrants to Canada". Canadian Jewish Studies / Études Juives Canadiennes 29 (June):12-32. Pg. 23.

\section{4}

Ibid, 23-24.

\section{5}

lbid, 24.

\section{6}

Ibid, 24.

\section{7}

Michael Greenstein, Third Solitudes: Tradition and Discontinuity in Jewish-Canadian Literature. (Ont.: McGill-Queen's University Press, 1989). Pg. 199.

\section{8}

Ibid, 199.

\section{9}

Ibid, 200.

\section{0}

Gerald Tulchinsky, Canada's Jews: a People's Journey. (Toronto: University of Toronto Press, 2008). Pg. 203.

\section{1}

On another similar note, consider the title of Kalman Weiser's chapter, "Vilna on the Saint-Lawrence: Montreal as the Would-Be Haven for Yiddish Culture", in Koffman's aforementioned volume No Better Home?: Jews, Canada, and the Sense of Belonging.

12

Howard et al. xix.

13

lbid, xx.

14

lbid, xxi.

15

Shelley Egoz, "Landscape and Identity in the Century of the Migrant," in The Routledge Companion to Landscape Studies, ed. Peter Howard et al. (London: Routledge, 2020), pp. 329-340.

16

Maggie Roe, "Landscape and Participation," in The Routledge Companion to Landscape Studies, ed. Peter Howard et al. (London: Routledge, 2020), pp. 402-417.

\section{7}

John J. Bradley and Amanda Kearney, “'You Whitefellas Pull It All Apart' Epistemic Learnings in Exploring Landscape," in The Routledge Companion to Landscape Studies, ed. Peter Howard et al. (London: Routledge, 2020), pp. 288-298.

\section{8}

Isis Brook, "Aesthetic Appreciation of Landscape," in The Routledge Companion to Landscape Studies, ed. Peter Howard et al. (London: Routledge, 2020), pp. 39-50.

19

Howard et al. xxiv. 


\section{0}

Ibid, xxvi.

\section{1}

Frances Swyripa, Storied Landscapes:

Ethno-Religious Identity and the Canadian

Prairies. (Winnipeg: University of Manitoba Press, 2010).

\section{2}

Michael Pasquier (2013). "Religion and the American Landscape." Religion Compass, 7: 137-148. pg. 139.

\section{3}

Ibid, 145,

\section{4}

Julia Brauch and Anna Lipphardt, eds., "Introduction: Exploring Jewish Space: An Approach," in Jewish Topographies: Visions of Space, Traditions of Place (London: Routledge, 2016). p. 6.

\section{5}

lbid, 4.

\section{6}

lbid, 5 .

\section{7}

Etan Diamond, "Religious Microspaces in a Suburban Environment: The Orthodox Jews of Thornhill, Ontario," in Jewish Topographies: Visions of Space, Traditions of Place, ed. Julia Brauch and Anna Lipphardt (London: Routledge, 2016), pp. 119-138. See also Etan Diamond, And I Will Dwell in Their Midst: Orthodox Jews in Suburbia (Chapel Hill, NC: University of North Carolina Press, 2000).

\section{8}

lbid, 121.

\section{9}

Ibid, 122.

\section{0}

For an article on this topic, see Yolande Cohen. (2020). “Enclaves Ethniques et stratégies résidentielles des Juifs à Toronto et Montréal". Canadian Jewish Studies / Études Juives Canadiennes 30 (November):83-114.

\section{1}

Henry Abramson (2001). '“Just Different:' The Last Jewish Family of Ansonville, Ontario". Canadian Jewish Studies / Études Juives Canadiennes 9 (January): 155-169.

\section{2}

Haya Bar-Itzhak, "Poland: A Materialized Settlement and a Metaphysical Landscape in Legends of Origin of Polish Jews," in Jewish Topographies: Visions of Space, Traditions of Place, ed. Julia Brauch and Anna Lipphardt (London: Routledge, 2016), pp. 161-180. Pg. 165.

\section{3}

Ibid, 170.

\section{4}

Though they don't necessarily account for mythic geography in the terms I describe here, the Museum of Jewish Montreal's (http:// imjm.ca) work with Jewish geography is a fascinating example of a Jewish organization thinking of Montreal in specifically Jewish terms. From their interactive map on their website to their brick and mortar location and walking tours, the Museum seeks to unveil a physical Jewish past and present in the city. A study of the work they do would fit well into the mandate described here.

\section{5}

Yael Zerubavel, "Desert and Settlement: Space Metaphors and Symbolic Landscapes in the Yishuv and Early Israeli Culture," in Jewish Topographies: Visions of Space, Traditions of Place, ed. Julia Brauch and Anna Lipphardt (London: Routledge, 2016), pp. 201-222. Pg. 205.

\section{6}

Ibid, 207.

37

Richard Menkis (2018), “Two Travellers and Two Canadian Jewish Wests." American Jewish History 102, no. 1 (01): 109-132. Pg. 111.

38

Eve Jochnowitz, "Foodscapes: The Culinary Landscapes of Russian-Jewish New York," in Jewish Topographies: Visions of Space, Traditions of Place, ed. Julia Brauch and Anna Lipphardt (London: Routledge, 2016), pp. 293308. Pg. 296.

\section{9}

Ibid, 296.

40

Dina Roginsky and Rina Cohen (2018). “Trading Jerusalem: Jewish-Arab Encounters in a Middle Eastern Restaurant in Toronto". Canadian Jewish Studies / Études Juives Canadiennes 26 (1): 75-98. 


\section{1}

Norma Baumel Joseph. “T'Beet: Situating Iraqi Jewish Identity through Food," in Everyday Sacred: Religion in Contemporary Quebec, ed. Hilary Kaell (Montréal: McGill-Queen's University Press, 2017), pp. 99-128. Pg. 99; See also Rabinovitch, Lara. “The Gravest Question': Romanian Jewish Migration to North America, 1900-1903". ProQuest Dissertations Publishing, 2012.

\section{2}

Miriam Lipis, "A Hybrid Place of Belonging: Constructing and Siting the Sukkah," in Jewish Topographies: Visions of Space, Traditions of Place, ed. Julia Brauch and Anna Lipphardt (London: Routledge, 2016), pp. 27-42. Pg. 28.

\section{3}

Along these lines, and in concert with the aforementioned work of the Museum of Jewish Montreal, see Stephanie Tara Schwarz's 2014 photographic essay on Jewish space in Montreal, "Spaces of the Jewish Public Library: A Photographic Essay". Canadian Jewish Studies / Études Juives Canadiennes 22 (November): 107-121.

\section{4}

Nicholas Bradley and Ella Soper, eds., "Greening the Maple: Canadian Ecocriticism in Context," in Greening the Maple: Canadian Ecocriticism in Context (Calgary: University of Calgary Press, 2013), pp. xiii-liv. Pg. xvi.

\section{5}

lbid, xv.

\section{6}

lbid, xv.

\section{7}

lbid, xix.

48

Ibid, xv.

\section{9}

Sean Kheraj, Inventing Stanley Park: An Environmental History. (Vancouver: UBC Press, 2013) Pg. 4

\section{0}

Jennifer, Bonnell, Reclaiming the Don: An Environmental History of Toronto's Don River Valley. (Toronto: University of Toronto Press, 2014). Pg. xix. lbid, xxiv. 